\title{
Will Britain stay within CERN?
}

\section{The British government's decision about membership of the European high-energy physics consortium cannot be put off much longer. Britain should stay in, but spend nothing extra.}

BEFORE the end of the year, probably before the end of November, the British government will be coming to a decision about the future of British membership of the European Nuclear Research Organization (really a high-energy physics laboratory) at Geneva. Even those who believe the British prime minister to have been needlessly beastly towards British academics will not envy her her task. It is a nasty decision to have to make

Britain has been a member of CERN since the very beginning, more than thirty years ago. As with other international organizations, membership is regulated by a treaty that binds the partner governments together. It is technically possible to withdraw by giving a year's notice, but nobody has so far taken advantage of that clause. Like pulling out of UNESCO, that must be a solemn decision.

The possibility that Britain might withdraw was first openly canvassed two years ago by the Kendrew committee (see page 755), itself the product of prolonged glooming by the British research councils about the large proportion of the basic research budget being spent on highenergy physics. It has now largely been forgotten that the same issue was addressed in 1968, when Sir Michael Swann spelled out the difficulties of keeping science alive in Britain while spending money with the big boys on high-energy physics; he was unwise to have singled out biology as in need of special protection. With the decline in the value of sterling in the past year, the membership fee alone is roughly $10 \mathrm{per}$ cent of total disposable research spending. Making full use of membership might cost as much again, but the research councils are deliberately cutting back on spending in this field and therefore do not let that happen.

Now it looks as if the compromise that might have made it possible for the British to continue as full members of CERN, the possibility of saving at least 15 per cent of the annual cost of running CERN, will not materialize. That is not surprising. CERN is embarking on the construction of its biggest machine yet, the electron accelerator called LEP. This can hardly be the time to ask it to slow down. Indeed, to do so is a kind of folly.

This is also, in any case, a time when other member governments are more enthusuastic about high-energy physics than Britain has been for several years. It can hardly make sense to ask that Italians, for example, who are just now Europe's cheerleaders of high-energy physics, should bottle up their enthuiasm to accommodate British cheeseparing. That, at least, is how it would seem to them.

In any case, Italians and others (such as the French) know that the British government cannot lightly withdraw from CERN. Doing so will only reinforce the impression now firmly established in Europe that the British are but second-rate Europeans. Why else has the British government spent two years (and two annual subscriptions) looking for a cheap way out?

Matters are now coming to a head because the end of the year is approaching. To be freed from its commitment in 1989 , Britain would have to give notice at the December meeting of the CERN council. It may win a few weeks of reprieve if its partners agree that the issue would be more calmly discussed early in the New Year. Either way, there is not much time left, and little enthusiasm outside the high-energy physics community in Britain for continued membership. What, in the circumstances, should the British government decide?

The first thing to say is that the highenergy physics community has been shiftless in its advocacy of its objectives. (Shiftless, which means carelessly indifferent, should be replaced by neglectful, or even feckless.) We all know that it would be important if the top quark were found, because it would make life a little more symmetrical, and that the new machine at CERN may do the trick. But what would happen afterwards? High-energy physicists easily become indignant, but have little to say beneath the huff and puff.

The simple truth is that nobody quite knows what high-energy physics is for. People engaged with the most promising kinds of theories (called "string theories") say that they may be even more promising than had been believed, but that there is not yet a sufficient basis for telling which of their many predictions is likely to be the more correct (in the Popperian sense). Nobody should complain at that, for novel theories are notoriously difficult to interpret. Even so, the silence of those who normally proclaim the benefits of the next machine has been a little reminiscent of the dog that never barked.

That is why it seems most likely that the decision about continued British membership of CERN will be made on grounds entirely unconnected with the subjectmatter of high-energy physics, with which politicians are not usually wellacquainted. It will instead be noted that the cost of British membership during 1987 will amount to $£ 57$ million, roughly 10 per cent of the disposable income of all the research councils put together, and that it would cost at least as much to make full use of the opportunity created by the CERN membership subscription. Especially because the research councils have not been persuaded in recent years to put up anything like that amount, their performance will be counted as a minus and membership of CERN will end.

That is what logic would dictate. The truth is that the British government will not relish being told off by its European partners for being a second-rate European, especially when it does not understand why first-rate Europeans (in the context of high-energy physics) are manifestly different. So, in the next few weeks, there will be an urge to find some different kind of compromise. This is what it could consist of.

Everybody concerned should first do a little arithmetic. The CERN subscription, now 10 per cent of total research council spending, is merely 5 per cent of the total fixed spending on academic research when the cost of university researchers' salaries is added in. Is that too big a burden? Many people in Britain who jib at 10 per cent would live happily with half as much. The snag, of course, is that there would be nothing left over with which to build the detector that might be transported to Geneva so as to recognize the new string particles that will eventually be described.

The simple diplomatic way of dealing with that awkwardness is to pretend it does not exist. If Britain said in December that it was proud to be a continuing member of the CERN consortium, and told only its own academics (when they asked) that there would be no extra money for research equipment, nobody on the European mainland would be especially downcast. Some might even be glad of the opportunity. That is why the British government's best course is to stay a member of CERN, but to let high-energy physics grants take their chances with others at the peer-review meetings.

John Maddox 